\title{
Diagnostic yield and agreement on fine-needle specimens from solid pancreatic lesions: comparing the smear technique to liquid- based cytology
}

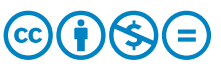

\section{Authors}

Priscilla A. van Riet ${ }^{1}$, Rutger Quispel ${ }^{2}$, Djuna L. Cahen ${ }^{1}$, Mieke C. Snijders-Kruisbergen ${ }^{3}$, Petri van Loenen ${ }^{3}$, Nicole S. Erler $^{4}$, Jan-Werner Poley', Lydi M. J. W. van Driel ${ }^{2}$, Sanna A. Mulder ${ }^{2}$, Bart J. Veldt ${ }^{2}$, Ivonne Leeuwenburgh ${ }^{5}$, MariePaule G. F. Anten ${ }^{5}$, Pieter Honkoop ${ }^{6}$, Annemieke Y. Thijssen ${ }^{6}$, Lieke Hol' ${ }^{1}$, Mohammed Hadithi ${ }^{7}$, Claire E. Fitzpatrick ${ }^{8}$, Ingrid Schot ${ }^{8}$, Jilling F. Bergmann ${ }^{9}$, Abha Bhalla ${ }^{9}$, Marco J. Bruno ${ }^{*}, 1$, Katharina Biermann ${ }^{*}, 3$

Institutions

1 Department of Gastroenterology, Erasmus MC University Medical Center Rotterdam, the Netherlands

2 Deparment of Gastroenterology and Hepatology, Reinier de Graaf Hospital, Delft, the Netherlands

3 Department of Pathology, Erasmus MC University Medical Center Rotterdam, the Netherlands

4 Department of Biostatistics, Erasmus MC University Medical Center Rotterdam, the Netherlands

5 Department of Gastroenterology and Hepatology, Sint Franciscus Hospital, Rotterdam, The Netherlands

6 Department of Gastroenterology and Hepatology, Albert Schweitzer Hospital, Dordrecht, The Netherlands

7 Department of Gastroenterology and Hepatology, Maasstad Hospital, Rotterdam, The Netherlands

8 Department of Gastroenterology and Hepatology, IJsselland Hospital, Rotterdam, The Netherlands

9 Department of Gastroenterology and Hepatology, HAGA, The Hague, The Netherlands

submitted 31.7.2019

accepted after revision 15.10.2019

Bibliography

DOI https://doi.org/10.1055/a-1038-4103 |

Endoscopy International Open 2020; 08: E155-E162

(c) Georg Thieme Verlag KG Stuttgart · New York eISSN 2196-9736

Corresponding author

P. A. van Riet, MD, Dept. of Gastroenterology and Hepatology, Erasmus MC University Medical Center Rotterdam, P.O Box 2040, 3015 CE Rotterdam, the Netherlands

Fax: +31107032908

p.vanriet@erasmusmc.nl

\section{ABSTRACT}

Background and study aims The traditional "smear technique" for processing and assessing endoscopic ultrasoundguided fine-needle aspiration (EUS-FNA) is sensitive to artifacts. Processing and evaluation of specimens collected in a liquid medium, liquid-based cytology (LBC) may be a solution. We compared the diagnostic value of EUS-FNA smears to $L B C$ in pancreatic solid lesions in the absence of rapid onsite evaluation (ROSE).

Patients and methods Consecutive patients who required EUS-FNA of a solid pancreatic lesion were included in seven hospitals in the Netherlands and followed for at least 12 months. Specimens from the first pass were split into two smears and a vial for LBC (using ThinPrep and/or Cell block). Smear and LBC were compared in terms of diagnostic accuracy for malignancy, sample quality, and diagnostic agreement between three cytopathologists.

Results Diagnostic accuracy for malignancy was higher for LBC (82\% (58/71)) than for smear (66\% (47/71), $P=0.04)$, but did not differ when smears were compared to ThinPrep (71\% (30/42), $P=0.56$ ) or Cell block (62\% (39/63), $P=0.61$ ) individually. Artifacts were less often present in ThinPrep (57\% (24/42), $P=0.02)$ or Cell block samples (40\% (25/63), $P<0.001)$ than smears $(76 \%(54 / 71))$. Agreement on malignancy was equally good for smears and $L B C(K=0.71$ versus $\mathrm{K}=0.70, P=0.98)$, but lower for ThinPrep $(\mathrm{K}=0.26, P=0.01)$ than smears.

Conclusion After a single pass, LBC provides higher diagnostic accuracy than the conventional smear technique for EUS-FNA of solid pancreatic lesions in the absence of ROSE. Therefore, LBC, may be an alternative to the conventional smear technique, especially in centers lacking ROSE.

\footnotetext{
* These authors contributed equally.
} 


\section{Introduction}

Pancreatic cancer is one of the most lethal solid tumors [1,2], but individualized therapies have improved progression-free survival $[3,4]$. Because these therapies depend on pre-therapeutic tissue analysis [5], endoscopic ultrasound (EUS)-guided tissue collection is increasingly being used for this purpose.

Although EUS-guided tissue sampling can reach diagnostic accuracy rates over $90 \%$, its outcome strongly depends on performer skills, sampling tools and techniques, and tissue processing [6]. Traditionally, fine-needle aspiration (FNA) needles have been used to collect cytological samples, which were smeared onto glass slides, the so-called smear technique. This technique is cheap, easy to use and available to the majority of EUS centers [7]. The downside of smears is that they are very sensitive to preparation artifacts [8,9]. A dedicated on-site pathologist (ROSE) can improve smear quality and hence diagnostic accuracy. However, in many EUS centers ROSE is not readily available due to costs and logistic issues [7]. As a result, FNA samples are often handled by the endoscopy staff, with varying diagnostic outcomes [10-13].

An alternative for ROSE is to collect FNA samples in a liquidbased medium, the so-called liquid-based cytology (LBC) technique. This technique makes samples less vulnerable to contamination or artifacts, as debris, blood, and exudates can easily be removed [14]. There are different LBC techniques, i.e. ThinPrep, Surepath, Cellprep plus, and Cell block. LBC slides mimic the in situ 3-dimensional tissue architecture and provide a homogeneous cell dispersion. They also allow pathologists to perform ancillary tissue tests that could previously only be performed on histological samples.

Although, LBC is more accurate than the conventional smears for the cytological diagnosis of cervical bile duct and gall bladder cancers $[15,16]$, its superiority for pancreatic cancer has not been proven. The outcome of studies that compared smear to LBC for pancreatic lesions vary greatly, and are difficult to compare due to heterogeneity in the used LBC techniques (i.e. ThinPrep, Surepath, Cellprep plus, and Cell block) $[9,17-26]$. As the ThinPrep and Cell block technique are two commonly used LBC techniques, we compared their diagnostic performance to the conventional smear technique for processing of FNA specimens from solid pancreatic lesions in the absence of an on-site pathologist.

\section{Patients and methods}

\section{Study design and patient selection}

This prospective multicenter study assessed whether LBC could replace smears for processing of pancreatic FNA specimens in centers lacking ROSE. For this, we compared EUS sample processing using the smear and LBC technique in terms of diagnostic accuracy, sample quality, and agreement on these parameters. Consecutive patients scheduled for EUS-FNA of a suspected solid pancreatic malignancy were included in a tertiary referral center and six regional community hospitals in the Netherlands between April 2016 and September 2017. Patients were followed for at least 12 months, until September 2018.
Prior to the study, the endoscopy personnel underwent 1-day FNA tissue preparation training to optimize their knowledge and skills. All harvested and prepared FNA samples were collected and reviewed by an expert cytopathologist and two experienced cytotechnicians from the pathology department at the Erasmus MC University Medical Center in Rotterdam, the Netherlands. The Medical Ethics Committee reviewed the study and granted a waiver of consent as the protocol did not interfere with local EUS-FNA sampling protocols (MEC-2016-022).

\section{EUS-guided tissue sampling}

All EUS-FNA procedures were performed according to a standard protocol, using a convex array echoendoscope (Pentax EG3870 UTK, Pentax EG-3270 UK, Olympus UTC 140/180, Olympus linear GF-UCT180, > Table1). Tissue sampling was performed by endosonographers who were formally trained for at least 1 year at a tertiary referral center, had 1 to 20 years of EUS experience, and perform at least 25 EUS-guided tissue sampling procedures annually. Patients were sampled using a 19-, 22- or 25-gauge FNA needle (EchoTip; Cook Medical or Expect; Boston Scientific). The number of passes, sampling technique, and use of additional techniques (e.g. applying negative suction with a syringe) were at the discretion of the performer.

\section{Specimen handling}

EUS-FNA specimens from the first pass were expelled from the needle using a stylet. Then, the specimen was split to prepare two separate glass slides using the smear technique. The remainder specimens from the same pass was collected in a liquid-based medium. Smears were performed using the "sandwich method" [27]. LBC was processed using thin layer preparation (ThinPrep, (Hologic) and/or the Cell block technique (Cellient automated Cell block system [Hologic]), the Agar technique, or Aalfix Cellblock, depending on local tissue handling protocols ( $\downarrow$ Table 1 ). Subsequent passes were handled according to local standards and not included in the study. Smears and LBC were prepared on-site, by the endoscopy personnel (endoscopy nurse or endosonographer). On-site pathological assistance was only allowed after the first pass, once study material was collected.

\section{Sample reviewing}

All study samples were anonymized and sent to the Erasmus MC University Medical Center in Rotterdam for review by an expert cytopathologist and two cytotechnicians who were specialized in pancreaticobiliary diseases. Reviewers were blinded to the final clinical and pathological outcome. Sample assessment and scoring were done individually by the reviewers. Case discussion was not allowed. Smears, thin layer samples, and Cell blocks were analyzed consecutively.

\section{Endpoints, scoring variables and definitions}

The primary endpoint was comparison of diagnostic accuracy of the conventional smear method to the LBC technique of FNA specimens from solid pancreatic lesions. Sample diagnosis was based on the Bethesda classification, and scored as non-diagnostic, benign, atypical, or malignant [28]. The reviewing ex- 
- Table 1 EUS-guided FNA and tissue processing specifics per center.

\begin{tabular}{|c|c|c|c|c|c|c|c|c|}
\hline Center & $\begin{array}{l}\text { EUS scope } \\
\text { type }\end{array}$ & $\begin{array}{l}\text { Annual } \\
\text { EUS-FNA per } \\
\text { endosono- } \\
\text { grapher }\end{array}$ & $\begin{array}{l}\text { ROSE } \\
\text { avail- } \\
\text { able }\end{array}$ & $\begin{array}{l}\text { Additional } \\
\text { techniques }\end{array}$ & $\begin{array}{l}\text { Smear prep- } \\
\text { aration }\end{array}$ & $\begin{array}{l}\text { Liquid cytology } \\
\text { medium }\end{array}$ & $\begin{array}{l}\text { Thin-lay- } \\
\text { er cytolo- } \\
\text { gy tech- } \\
\text { nique }\end{array}$ & $\begin{array}{l}\text { Cellblock } \\
\text { tech- } \\
\text { nique }\end{array}$ \\
\hline $\begin{array}{l}\text { Albert Schweit- } \\
\text { zer Hospital, } \\
\text { Dordrecht }\end{array}$ & $\begin{array}{l}\text { Olympus, } \\
\text { linear GF- } \\
\text { UCT180 }\end{array}$ & 25 & Yes & $\begin{array}{l}\text { Slow pull } \\
\text { or Suction }\end{array}$ & $\begin{array}{l}\text { Air dry, } \\
\text { Hemocolor }\end{array}$ & Cytolyt & ThinPrep & $\begin{array}{l}\text { Cellient } \\
\text { Hologic }\end{array}$ \\
\hline $\begin{array}{l}\text { Reinier de Graaf } \\
\text { Hosptial, Delft }\end{array}$ & $\begin{array}{l}\text { Olympus, } \\
\text { linear GF- } \\
\text { UCT180 }\end{array}$ & 30 & No & Slow pull & $\begin{array}{l}\text { Air dry, No } \\
\text { stain }\end{array}$ & $\begin{array}{l}\text { Cytolyt, or Poly- } \\
\text { transportbuffer }\end{array}$ & ThinPrep & Agar \\
\hline $\begin{array}{l}\text { Erasmus MC Uni- } \\
\text { versity Medical } \\
\text { Center Rotter- } \\
\text { dam }\end{array}$ & $\begin{array}{l}\text { Pentax EG- } \\
3870 \text { UTK } \\
\text { Olympus } \\
\text { UTC } 140 / \\
180\end{array}$ & 50 & Yes & $\begin{array}{l}\text { Slow pull } \\
\text { or Suction }\end{array}$ & $\begin{array}{l}\text { Air dry, Diff } \\
\text { quick }\end{array}$ & Cytolyt & ThinPrep & $\begin{array}{l}\text { Cellient } \\
\text { Hologic }\end{array}$ \\
\hline $\begin{array}{l}\text { Haga Hospital, } \\
\text { The Hague }\end{array}$ & $\begin{array}{l}\text { Olympus, } \\
\text { linear GF- } \\
\text { UCT180 }\end{array}$ & 25 & Yes & Slow pull & $\begin{array}{l}\text { Air dry, Diff } \\
\text { quick }\end{array}$ & Formalin & None & $\begin{array}{l}\text { Paraffin } \\
\text { cellblock }\end{array}$ \\
\hline $\begin{array}{l}\text { ljsselland Hospi- } \\
\text { tal, Rotterdam }\end{array}$ & $\begin{array}{l}\text { Olympus, } \\
\text { linear GF- } \\
\text { UCT180 }\end{array}$ & 25 & Yes & Slow pull & $\begin{array}{l}\text { Air dry, Diff } \\
\text { quick Giemsa }\end{array}$ & CytoRichRed & None & Agar \\
\hline $\begin{array}{l}\text { Maasstad Hospi- } \\
\text { tal, Rotterdam }\end{array}$ & $\begin{array}{l}\text { Pentax EG- } \\
3270 \text { UK } \\
\text { Olympus } \\
\text { linear GF- } \\
\text { UCT180 }\end{array}$ & 30 & No & Slow pull & $\begin{array}{l}\text { Air dry, Diff } \\
\text { quick }\end{array}$ & CytoRichRed & None & $\begin{array}{l}\text { Aalfix cell- } \\
\text { block }^{1}\end{array}$ \\
\hline $\begin{array}{l}\text { Sint Franciscus } \\
\text { Hospital, Rotter- } \\
\text { dam }\end{array}$ & $\begin{array}{l}\text { Pentax } \\
\text { EUS-scope }\end{array}$ & 20 & No & $\begin{array}{l}\text { Slow pull or } \\
\text { Suction }\end{array}$ & $\begin{array}{l}\text { Air dry, No } \\
\text { stain }\end{array}$ & CytoRichRed & None & Agar \\
\hline
\end{tabular}

pert cytopathologist determined the final sample diagnosis. Gold standard diagnosis was based on the surgical resection specimens in operated patients, or on a compatible clinical disease course during a 12-month follow-up period. Solid pseudopapillary neoplasms (SPN) and NET grade 2 and 3 were classified as malignant $[29,30]$.

Secondly, we compared sample quality, defined as sample cellularity (<or $>50 \%$ target cells) and presence of preparation artifacts, such as poor fixation, thick smear/clots, obscuring blood or inflammation, or cytolysis (no/yes). In addition, we compared interobserver agreement on sample diagnosis and quality among the three reviewers between the two techniques.

Other parameters that were scored included needle size, target lesion characteristics (location, size), number of needle passes performed, type of LBC medium used, and procedurerelated complications (pancreatitis, infection, bleeding, other).

\section{Statistics}

Diagnostic accuracy and sample quality were compared between the smear and LBC technique, and were analyzed using logistic mixed effects models [31] with subject- and study cen- ter-specific (random) intercepts. This method allows taking into account the clustering structure of this multicenter trial, i. e., that observations from the same study center may be correlated. Separate models were fitted for comparison of SMEAR vs LBC and SMEAR vs ThinPrep vs Cell Block. Statistical significance was established as $P<0.05$ (two-tailed).

Interobserver agreement among reviewers was calculated using kappa statistics [Fleiss' $\mathrm{K}$-statistic and $95 \%$ confidence intervals (Cls)]. $\mathrm{k}$ - statistics were interpreted according to convention of Landis and Koch; <0, no agreement; $0-0.20$ slight agreement; $0.21-0.40$, fair agreement; $0.41-0.60$, moderate agreement; 0.61-0.80, substantial agreement; and 0.81-1.0; almost perfect agreement. Because not all samples were evaluated for both LBC methods, ThinPrep and Cell block, some of the ratings were missing. To compare agreement coefficients, the coefficient was then calculated based on the samples for which all ratings of the methods in the current comparison were available. In settings where the agreement coefficients of three methods were compared, three pairwise tests were used and $P$ values were corrected for multiple testing using Holm's procedure [32]. For this, the $P$ values presented in this manuscript have been multiplied by the number of comparisons. 
- Table 2 Case characteristics.

\begin{tabular}{|l|c|}
\hline Variables & $\begin{array}{c}\text { Cases } \\
\text { (n=71) }\end{array}$ \\
\hline Target lesion location, $n$ (\%) & \\
\hline - Head & $34(48)$ \\
\hline - Uncinate process & $6(9)$ \\
\hline - Neck & $4(6)$ \\
\hline - Corpus & $14(20)$ \\
\hline - Tail & $13(18)$ \\
\hline Target lesion size (mm), mean \pm SD & $31.0 \pm 1.37$ \\
\hline FNA needle size, $n$ (\%) & $1(1)$ \\
\hline - 19-gauge & $27(38)$ \\
\hline - 22-gauge & $43(61)$ \\
\hline - 25-gauge & $3(2-3)$ \\
\hline Number of passes, median (IQR) & \\
\hline Gold standard diagnosis & $4(6)$ \\
\hline - Benign & $3(4)$ \\
\hline - Atypical (NET, pancreatitis) & $64(90)$ \\
\hline - Malignant & \\
\hline SD, standard deviation; FNA, fine-needle aspiration; IQR, interquartile \\
\hline
\end{tabular}

Analyses were carried out using R version 3.5.1 [33], and SPSS version 23, Statistical Package for the Social Sciences, SPSS Inc., Chicago, Illinois, United States.

\section{Power calculation}

To determine the power needed for this study, we first performed a pilot study to assess the diagnostic accuracy for malignancy for pancreatic EUS-FNA specimens prepared using the smears and LBC method in the Erasmus MC University Medical Center. A difference in diagnostic accuracy of $20 \%$ between smear and LBC was found, and considered clinically relevant. We estimated that to find such a difference, a sample size of 59 to 72 pairs would have $80 \%$ power to detect a difference in proportions of 0.250 when the proportion of discordant pairs is expected to be between $0.500-0.600$ and the method of analysis is a McNemar's test of equality of paired proportions with a 0.050 two-sided significance level.

\section{Results}

\section{Case characteristics}

A total of 71 cases were included, of which lesion and sampling characteristics are listed in Table 2 . No procedure-related complications were recorded. Final diagnosis comprised 64 (90\%) malignancies, three (4\%) atypical cases, including two neuroendocrine tumors and one case of pancreatitis, and four (6\%) benign cases. This diagnosis was based on resection specimens in 19 (29\%), additional tissue biopsy (i.e. peritoneal, brain, lymph node biopsy) in 13 (20\%), and follow-up in 33 (51\%) cases.

\section{Diagnostic accuracy and sample quality for smear versus LBC}

Overall, diagnostic accuracy for malignancy of the first pass was $86 \%(61 / 71)$. Accuracy was higher for samples processed using LBC than with the conventional smear technique ( $82 \%$ versus $66 \%$, OR $2.6295 \% \mathrm{Cl} 1.13-6.79, P=0.03)$. Overall diagnostic accuracy according to Bethesda was $80 \%$ (57/71). For this classification, smears and LBC performed equally well (51\% versus $59 \%$, OR $1.4495 \% \mathrm{Cl} 0.73-2.92, P=0.30)$. Comparing the diagnostic accuracy for malignancy and the Bethesda classification of smears to both LBC techniques individually did not result in a significant difference in diagnostic accuracy ( $>$ Table 3 ). Cell block had lower sample cellularity than smear (OR $0.3995 \% \mathrm{Cl}$ $0.18-0.82, P=0.01, \nabla$ Table 4 ), but there was no clear evidence of a difference between ThinPrep and smear (OR $0.5195 \% \mathrm{Cl}$ $0.21-1.16, P=0.11)$. Sample quality, in terms of artifacts, was better for both LBC techniques as compared to the smears ( Table 4).

- Table 3 Overall diagnostic accuracy, and per tissue processing technique compared to smear.

\begin{tabular}{|c|c|c|c|c|c|c|}
\hline Sampling technique & $\begin{array}{l}\text { Accuracy for } \\
\text { malignancy } \\
\text { n (\%) }\end{array}$ & $\begin{array}{l}\text { OR } \\
(95 \% \mathrm{Cl})\end{array}$ & $P$ value & $\begin{array}{l}\text { Accuracy for } \\
\text { Bethesda } \\
\text { n (\%) }\end{array}$ & OR $(95 \% \mathrm{CI})$ & $P$ value \\
\hline Overall $(n=71)$ & $61(86)$ & & & $57(80)$ & & \\
\hline Smear $(n=71)$ & $47(66)$ & $1.92(0.75-4.83)$ & 1 & $36(51)$ & $1.03(0.62-1.71)$ & 1 \\
\hline $\operatorname{LBC}(n=71)$ & $58(82)$ & $2.62(1.13-6.79)$ & 0.03 & $42(59)$ & $1.44(0.73-2.92)$ & 0.30 \\
\hline ThinPrep $(n=42)$ & $30(71)$ & $1.29(0.52-3.26)$ & 0.59 & $26(62)$ & $1.61(0.74-3.76)$ & 0.24 \\
\hline Cell block $(n=63)$ & $39(62)$ & $0.78(0.78-1.69)$ & 0.53 & $22(35)$ & $0.51(0.24-1.03)$ & 0.07 \\
\hline
\end{tabular}


- Table4 Sample quality per tissue processing technique, compared to smear.

\begin{tabular}{|c|c|c|c|c|c|c|}
\hline Sampling technique & $\begin{array}{l}\text { Artifacts } \\
\text { n (\%) }\end{array}$ & $\begin{array}{l}\text { OR } \\
(95 \% \mathrm{Cl})\end{array}$ & $P$ value & $\begin{array}{l}\text { Cellularity } \\
\text { n (\%) }\end{array}$ & $\begin{array}{l}\text { OR } \\
(95 \% \mathrm{CI})\end{array}$ & $P$ value \\
\hline Smear $(n=71)$ & $54(76)$ & $4.09(1.54-15.16)$ & 1 & $35(49)$ & $0.97(0.43-2.04)$ & 1 \\
\hline \multicolumn{7}{|l|}{$\operatorname{LBC}(n=71)$} \\
\hline ThinPrep $(n=42)$ & $24(57)$ & $0.32(0.12-0.82)$ & 0.02 & $14(33)$ & $0.51(0.21-1.16)$ & 0.11 \\
\hline Cell block $(n=63)$ & $25(40)$ & $0.15(0.05-0.35)$ & $<0.001$ & $18(29)$ & $0.39(0.18-0.82)$ & 0.01 \\
\hline
\end{tabular}

\section{Diagnostic agreement for smear vs LBC}

The diagnostic agreement among the cytopathologist and the two cytotechnicians was equally good for identifying malignancy in smears $(\mathrm{K}=0.71,95 \% \mathrm{Cl} 0.57-0.84)$ and LBC samples $(\mathrm{K}=$ $0.70,95 \% \mathrm{Cl} 0.55-0.86, P=0.98)$. The same was true for their agreement on the Bethesda classification $(\kappa=0.70,95 \% \mathrm{Cl}$ $0.57-0.83$ vs $\mathrm{K}=0.64,95 \% \mathrm{Cl} 0.50-0.78, P=0.55)$. When ThinPrep ( $\mathrm{\kappa}=0.26,95 \% \mathrm{Cl} 0.04-0.48)$ and Cell block $(\kappa=0.79,95 \%$ $\mathrm{Cl}$ 0.66-0.92) were assessed separately, agreement on presence of malignancy was comparable for Cell block and smears ( $\kappa=0.79$ vs. $\kappa=0.73$, adjusted $P=0.53$ ), but lower for ThinPrep than smears ( $K=0.261$ vs $K=0.640$, adjusted $P=0.04$ ). Similar results were found for the Bethesda classification ( $\triangleright$ Fig.1). Agreement on presence of artifacts was low for all processing techniques, and did not differ significantly between processing

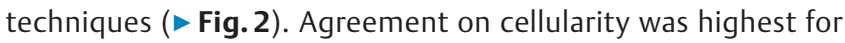
Cell block $(\mathrm{K}=0.64,95 \% \mathrm{Cl} 0.48-0.81)$ and smears $(\mathrm{K}=0.60$, $95 \% \mathrm{Cl} 0.46-0.75)$, and lowest for ThinPrep $(\kappa=0.35,95 \% \mathrm{Cl}$ $0.14-0.56)$.

\section{Discussion}

Liquid-based cytology using ThinPrep and Cell block provides higher diagnostic accuracy than and a comparable agreement to the conventional smear technique after a single FNA pass from solid pancreatic lesions in the absence of an on-site pathologist. LBC, therefore, is a good alternative to the smear technique in the absence of ROSE. The higher diagnostic agreement for Cell block than ThinPrep advocates for implementation of the Cell block technique for LBC.

The first explanation for the higher diagnostic accuracy of LBC than smear seems to be its lower artifact rate. It is generally accepted that smears are vulnerable to preparation artifacts, which induces interpretation errors, and may result in a lower diagnostic accuracy [25]. Despite the fact that the endoscopy staff in the current study participated in smear preparation training to optimize their performance before initiation of the study, $76 \%$ of the smears still contained artifacts. This was much higher than the artifact rate for the Cell block (39.7\%) and ThinPrep samples (57.1\%).

Besides a low artifact rate, the histology-like look of Cell block samples likely contributes to easier interpretation and matching interobserver agreement. It has previously been re- ported that pathologists prefer histology or Cell block over conventional cytology preparation, as its appearance is much closer to the in situ tissue architecture [8]. Furthermore, LBC allows for additional testing, such as immunohistochemistry, which may be decisive in challenging diagnostic cases such as autoimmune pancreatitis, or differentiation between metastatic or primary disease. Although agreement was higher for Cell block than for ThinPrep, it should also be taken into account that special training of cytotechnicians and pathologists is a prerequisite for accurate interpretation of these different LBC techniques [8]. Therefore, choosing the optimal LBC technique will depend upon the preference and experience of the local pathologists.

The finding that sample cellularity was lower for LBC than for smears does not seem to match with its high diagnostic accuracy and agreement. It may be explained by the more homogeneous cell dispersion of LBC samples. This allows for better assessment of cell morphology, but may give the impression of a less "cellular sample." On the other hand, highly cellular smears may be scored as containing more than enough target cells, but if cells are packed in thick layers, this only hampers the interpretation. Despite the lack of a clear definition of "FNA sample cellularity," higher cellularity has been associated with higher DNA yield for molecular testing [14]. Therefore, it is crucial to determine the specific purpose of EUS-guided tissue collection in advance, and discuss this with the involved pathologist.

It is challenging to compare our findings to previous reports, since EUS-FNA protocols and tissue handling and processing techniques vary greatly. So far, 11 studies have compared the smear to the LBC technique for solid pancreatic lesions [9, 1726]. Six of them reported a higher diagnostic accuracy for smears than LBC $[9,18,21-23,26]$. Half of these studies used ROSE $[18,21,22]$. Overall, only three of the 11 studies that compared smear to LBC were performed without ROSE [9, 20, 26]. Of these studies, two found a benefit of smear over LBC $[9,26]$ and one found a benefit for LBC, using another ThinPrep-like solution (Surepath) [29]. Each study used different ThinPrep solutions, limiting a direct comparison with our results. Of the studies that reported a diagnostic benefit for LBC, two of three used the Cell block rather than the ThinPrep technique, which seems to correspond with our findings [17,24, 25]. Lastly (or finally), none of the above-mentioned studies assessed diagnostic agreement on the different techniques. 


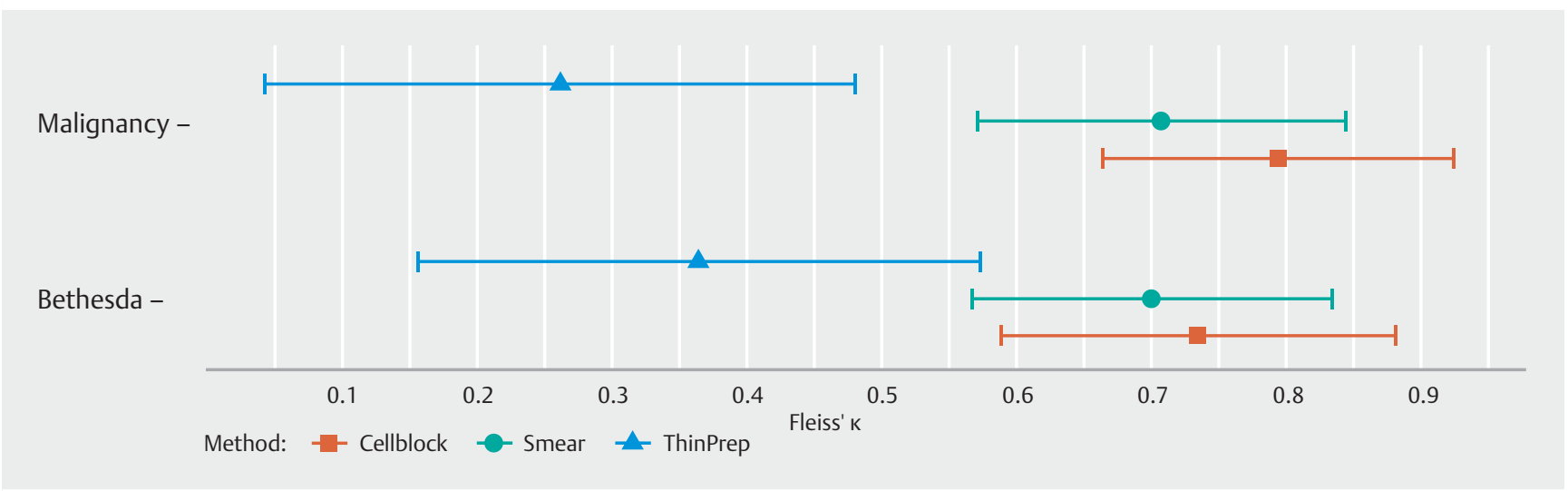

- Fig. 1 Agreement on diagnostic accuracy of malignancy and the Bethesda classification for smear, ThinPrep and Cell block.

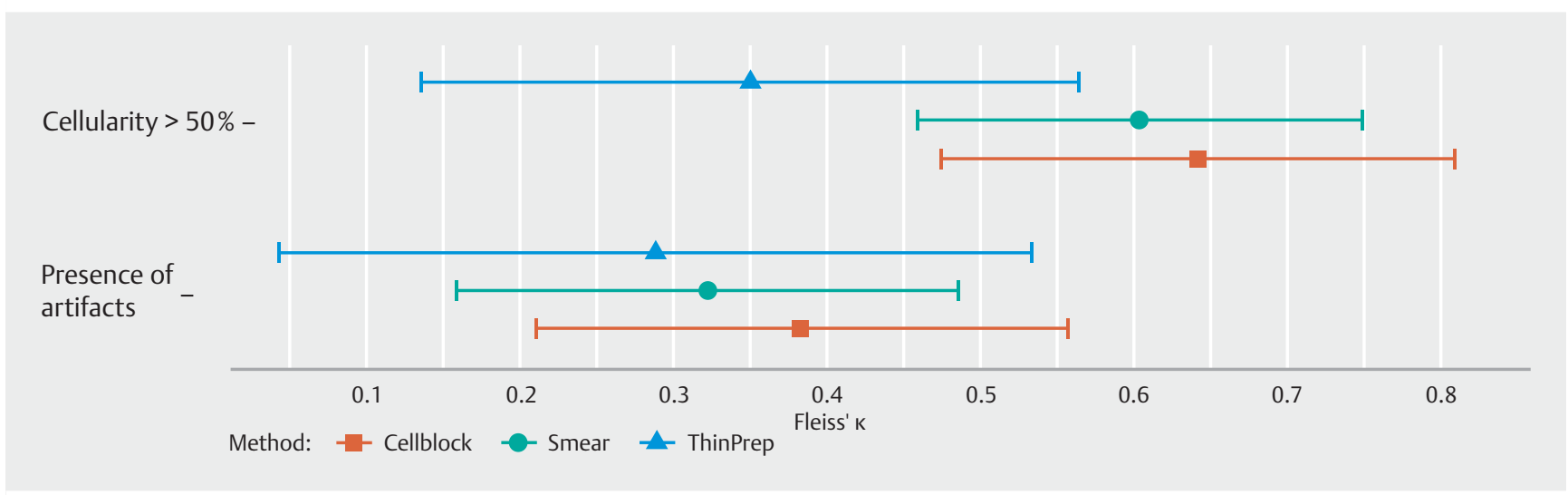

Fig. 2 Agreement on sample cellularity and presence of artifacts for smear, ThinPrep and Cell block.

Compared to results in other studies, our overall diagnostic accuracy rate of $86 \%$ is rather high, considering the fact that material was collected from the first needle pass only. Previous studies mostly based their results on several passes. Moreover, we split the material from this first pass for smear and LBC. As a result, our samples likely contained less material as compared to other study settings. Therefore, our diagnostic accuracy rates underestimate the true diagnostic accuracy rates in our practices. Furthermore, the diagnostic accuracy of each preparation technique alone was somewhat lower than LBC overall. The most likely explanation for this is that ThinPrep and Cell block are complementary techniques that provide samples with a different phenotype and diagnostic possibilities.

Our study has some limitations. An important limitation of studies on EUS-guided tissue sampling is lack of uniform guidelines on optimal sampling and tissue-handling techniques. Therefore, the resulting intercenter variation should always be considered, and may hamper general extrapolation of our findings. Second, we did not power our study to perform additional subgroup analysis. Furthermore, although the participating endosonographers who performed the smears participated in hands-on FNA tissue preparation training, their experience is not comparable to that of on-site pathologists. Therefore, this may have limited the diagnostic accuracy of the smears. An- other limitation is that the reviewing pathology staff could not be blinded to the processing technique, as their appearance differs accordingly. Furthermore, we did not perform a cost-effectiveness analysis due to differences in local EUS-protocols between the participating centers. Last, we only assessed the performance for both processing techniques for the first FNA pass, as our study was primarily designed to verify the concept that LBC could replace smears in clinical practice, not to evaluate the absolute diagnostic accuracy of the two techniques. Our data suggest that, in the absence of ROSE, LBC may replace smears.

Although LBC may replace smear preparation of pancreatic FNA specimens, in the absence of ROSE, its clinical importance may be questioned because there is growing evidence of the superiority of FNB over FNA [34,35]. It would be interesting to directly compare the diagnostic accuracy of FNA specimens in liquid-based cytology to FNB cores in formalin, preferably in an international multicenter setting. Furthermore, it should be noted that tissue collection for liquid preparation techniques is easy for the endosonographer, but requires a well-equipped pathology laboratory and trained personnel. Therefore, introducing and implementing novel techniques and innovations for EUS-guided tissue sampling should always be done in close cooperation with the pathology department. 


\section{Conclusion}

In conclusion, absent an on-site pathologist, the diagnostic accuracy of EUS-FNA for solid pancreatic lesions can be increased with the LBC technique as compared to the conventional smear technique. Because LBC provided for higher diagnostic accuracy and comparable interobserver agreement than smears, it may be routinely implemented in EUS centers lacking ROSE. The higher agreement for Cell block advocates for implementation of Cell block rather than ThinPrep. However, providing optimal EUS-tissue sampling depends on many factors, including experience and skills of the involved endoscopy and pathology team, and starts with the determination of the diagnostic or therapeutic purpose of tissue acquisition.

\section{Competing interests}

None

\section{References}

[1] Rahib L, Smith BD, Aizenberg R et al. Projecting cancer incidence and deaths to 2030: the unexpected burden of thyroid, liver, and pancreas cancers in the United States. Cancer Res 2014; 74: 2913-2921

[2] Siegel RL, Miller KD, Jemal A. Cancer statistics, 2018. CA Cancer ] Clin 2018; 68: 7-30

[3] Katz MH, Shi Q, Ahmad SA et al. Preoperative modified FOLFIRINOX treatment followed by capecitabine-based chemoradiation for borderline resectable pancreatic cancer: Alliance for Clinical Trials in Oncology Trial A021101. JAMA Surg 2016; 151: e161137

[4] Murphy JE, Wo JY, Ryan DP et al. Total neoadjuvant therapy with FOLFIRINOX followed by individualized chemoradiotherapy for borderline resectable pancreatic adenocarcinoma: a phase 2 clinical trial. JAMA Oncol 2018; 4: 963-969

[5] Ducreux M, Cuhna AS, Caramella C et al. Cancer of the pancreas: ESMO Clinical Practice Guidelines for diagnosis, treatment and followup. Ann Oncol 2015; 26: v56-68

[6] Polkowski M, Jenssen C, Kaye P et al. Technical aspects of endoscopic ultrasound (EUS)-guided sampling in gastroenterology: European Society of Gastrointestinal Endoscopy (ESGE) Technical Guideline. Endoscopy 2017; 49: 989-1006

[7] van Riet PA, Cahen DL, Poley JW et al. Mapping international practice patterns in EUS-guided tissue sampling: outcome of a global survey. Endosc Int Open 2016; 4: E360-E370

[8] Biermann K, Lozano Escario MD, Hebert-Magee $S$ et al. How to prepare, handle, read, and improve EUS-FNA and fine-needle biopsy for solid pancreatic lesions: The pathologist's role. Endosc Ultrasound 2017; 6: S95-S98

[9] Kopelman Y, Marmor S, Ashkenazi I et al. Value of EUS-FNA cytological preparations compared with cell block sections in the diagnosis of pancreatic solid tumours. Cytopathology 2011; 22: 174-178

[10] Hikichi T, Irisawa A, Bhutani MS et al. Endoscopic ultrasound-guided fine-needle aspiration of solid pancreatic masses with rapid on-site cytological evaluation by endosonographers without attendance of cytopathologists. J Gastroenterol 2009; 44: 322-328

[11] Nayar MK, Chatterjee S, Wadehra V et al. Does on-site adequacy assessment by cytotechnologists improve results of EUS guided FNA of solid pancreaticobiliary lesions? JOP 2013; 14: 44-49
[12] Alsohaibani F, Girgis S, Sandha GS. Does onsite cytotechnology evaluation improve the accuracy of endoscopic ultrasound-guided fineneedle aspiration biopsy? Can J Gastroenterol 2009; 23: 26-30

[13] Ecka RS, Sharma M. Rapid on-site evaluation of EUS-FNA by cytopathologist: an experience of a tertiary hospital. Diagn Cytopathol 2013; 41: 1075-1080

[14] da Cunha Santos G, Saieg MA. Preanalytic specimen triage: Smears, cell blocks, cytospin preparations, transport media, and cytobanking. Cancer Cytopathol 2017; 125: 455-464

[15] Bernstein SJ, Sanchez-Ramos L, Ndubisi B. Liquid-based cervical cytologic smear study and conventional Papanicolaou smears: a metaanalysis of prospective studies comparing cytologic diagnosis and sample adequacy. Am J Obstet Gynecol 2001; 185: 308-317

[16] Meara RS, Jhala D, Eloubeidi MA et al. Endoscopic ultrasound-guided FNA biopsy of bile duct and gallbladder: analysis of 53 cases. Cytopathology 2006; 17: 42-49

[17] Cermak TS, Wang B, DeBrito P et al. Does on-site adequacy evaluation reduce the nondiagnostic rate in endoscopic ultrasound-guided fineneedle aspiration of pancreatic lesions? Cancer Cytopathol 2012; 120: 319-325

[18] de Luna R, Eloubeidi MA, Sheffield MV et al. Comparison of ThinPrep and conventional preparations in pancreatic fine-needle aspiration biopsy. Diagn Cytopathol 2004; 30: 71-76

[19] Haba S, Yamao K, Bhatia V et al. Diagnostic ability and factors affecting accuracy of endoscopic ultrasound-guided fine needle aspiration for pancreatic solid lesions: Japanese large single center experience. J Gastroenterol 2013; 48: 973-981

[20] Hashimoto S, Taguchi H, Higashi M et al. Diagnostic efficacy of liquidbased cytology for solid pancreatic lesion samples obtained with endoscopic ultrasound-guided fine needle aspiration: A propensity score-matched analysis. Dig Endosc 2017; 29: 608-616

[21] LeBlanc JK, Emerson RE, Dewitt J et al. A prospective study comparing rapid assessment of smears and ThinPrep for endoscopic ultrasoundguided fine-needle aspirates. Endoscopy 2010; 42: 389-394

[22] Lee JK, Choi ER, Jang TH et al. A prospective comparison of liquidbased cytology and traditional smear cytology in pancreatic endoscopic ultrasound-guided fine needle aspiration. Acta Cytol 2011; 55 : 401-407

[23] Lee KJ, Kang YS, Cho MY et al. Comparison of cytologic preparation methods in endoscopic ultrasound-guided fine needle aspiration for diagnosis of pancreatic adenocarcinoma. Pancreatology 2016; 16: 824-828

[24] Noda Y, Fujita N, Kobayashi G et al. Diagnostic efficacy of the cell block method in comparison with smear cytology of tissue samples obtained by endoscopic ultrasound-guided fine-needle aspiration. J Gastroenterol 2010; 45: 868-875

[25] Qin SY, Zhou Y, Li P et al. Diagnostic efficacy of cell block immunohistochemistry, smear cytology, and liquid-based cytology in endoscopic ultrasound-guided fine-needle aspiration of pancreatic lesions: a single-institution experience. PLoS One 2014; 9: e108762

[26] Yeon MH, Jeong HS, Lee HS et al. Comparison of liquid-based cytology (CellPrepPlus) and conventional smears in pancreaticobiliary disease. Korean J Intern Med 2018; 33: 883-892

[27] Drijver MEBJS. Routine cytological staining techniques, theoretical background and practice. Palgrave Macmillan; 1986: 256

[28] Pitman MB, Centeno BA, Ali SZ et al. Standardized terminology and nomenclature for pancreatobiliary cytology: The Papanicolaou Society of Cytopathology Guidelines. Cytojournal 2014; 11: 3

[29] Fletcher CD, Berman JJ, Corless C et al. Diagnosis of gastrointestinal stromal tumors: A consensus approach. Hum Pathol 2002; 33: 459465

[30] Iwashita T, Yasuda I, Mukai T et al. Macroscopic on-site quality evaluation of biopsy specimens to improve the diagnostic accuracy during 
EUS-guided FNA using a 19-gauge needle for solid lesions: A singlecenter prospective pilot study (MOSE study). Gastrointest Endosc 2015; 81: 177-185

[31] Verbeke GMaG. Models for Discrete Longitudinal Data. Springer; 2006

[32] Holm S. A simple sequentially rejective multiple test procedure. Scand J Statist 1979; 2: 65-70

[33] Team RC. R: a language and environment for statistical computing. Vienna, Austria: R Foundation for Statistical Computing; 2018
[34] Cheng B, Zhang Y, Chen Q et al. Analysis of fine-needle biopsy vs fineneedle aspiration in diagnosis of pancreatic and abdominal masses: a prospective, multicenter, randomized controlled trial. Clin Gastroenterol Hepatol 2018; 16: 1314-1321

[35] Li H, Li W, Zhou QY et al. Fine needle biopsy is superior to fine needle aspiration in endoscopic ultrasound guided sampling of pancreatic masses. Medicine 2018; 13: 97 